\title{
KREATIVITAS DALAM PEMBELAJARAN SENI MUSIK DI SEKOLAH DASAR: SUATU TINJAUAN KONSEPTUAL
}

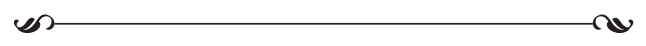
Qonita Fitra Yuni

SMAN 1 Suboh Situbondo, Jawa Timur, Indonesia

o con

\begin{abstract}
CREATIVITY ON MUSICAL LEARNING IN ELEMENTARY SCHOOL: CONCEPTUAL REVIEW: The purpose of musical learning in elementary school is to create and develop students' personality. In musical learning at school, students have to get musical experience through listening activity, playing music, singing a song, reading music, and dancing to follow the music, so students get intact and comprehensive description about that song. In order to create a qualified music, so that could be realized only by a professional teacher who could create fun and creative learning. Thus, this article aimed to reveal: 1) how is the musical teacher's role in elementary learning process, 2) how are the ways of elementary musical teacher to improve his/her professionality in developing musical skill mastery, and 3) how is the learning implementation through musical learning approach based creativity in elementary school.
\end{abstract}

Key words: creativity, musical learning, musical teacher

\section{A. Pendahuluan}

Sejak dikeluarkannya Peraturan Menteri Pendidikan Dan Kebudayaan Republik Indonesia Nomor 81A Tahun 2013 Tentang Implementasi Kurikulum 2013, maka implementasi kurikulum pada sekolah dasar/madrasah ibtidaiyah (SD/MI), sekolah menengah pertama/madrasah tsanawiyah (SMP/MTs), sekolah menengah atas/madrasah aliyah (SMA/MA), dan sekolah menengah kejuruan/madrasah aliyah kejuruan (SMK/MAK) dilakukan secara bertahap mulai tahun pelajaran 2013/2014. Kurikulum 2013 bertujuan membangun kesejahteraan berbasis peradaban, di mana modal sosial, modal budaya, modal pengetahuan/keterampilan menjadi modal dasar peradaban untuk membangun sumber daya manusia yang sejahtera.

Kesenian, khususnya Pembelajaran Seni Musik juga turut diwujudkan 


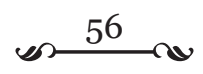

dan diinternalisasikan sebagai pembelajaran yang mendorong anak untuk kreatif dan mampu berkespresi sesuai dengan perkembangannya. Pembelajaran Seni Musik masuk dalam Seni Budaya dan Prakarya (SBDP), pembelajarannya dilakukan secara tematik dengan mata pelajaran lain dan disesuaikan dengan tema dan subtema yang telah ada.

Pada dasarnya, tujuan pendidikan musik pada semua jenjang pendidikan sama. Pembelajaran musik di sekolah mempunyai tujuan untuk: (1) memupuk rasa seni pada tingkat tertentu dalam diri tiap anak melalui perkembangan kesadaran musik, tanggapan terhadap musik, kemampuan mengungkapkan dirinya melalui musik, sehingga memungkinkan anak mengembangkankepekaanterhadapduniasekelilingnya;(2)mengembangkan kemampuan menilai musik melalui intelektual dan artistik sesuai dengan budaya bangsanya; dan 3) dapat dijadikan bekal untuk melanjutkan studi ke pendidikan musik yang lebih tinggi (Jamalus, 1998: 91).

Tujuan pendidikan musik di sekolah dasar adalah untuk membentuk dan membina kepribadian siswa. Kepekaan estetis dan nilai-nilai positif dari kegiatan bermusik diharapkan dapat membina perilaku, sikap dan watak siswa. Dari sini, nampak bahwa upaya pembentukan pribadi siswa mendapat porsi yang lebih utama dalam pembelajaran musik di sekolah. Hal ini sesuai dengan tujuan pendidikan nasional, yaitu membentuk manusia yang beriman dan bertakwa kepada Tuhan Yang Maha Esa, beretika (beradab dan berwawasan budaya bangsa Indonesia), memiliki nalar (maju, cukup cerdas, kreatif, inovatif, dan bertanggung jawab), berkemampuan komunikasi sosial (tertib dan sadar hukum, kooperatif dan kompetitif, demokratis), dan berbadan sehat sehingga menjadi manusia mandiri (Mulyasa, 2003: 21).

Oleh karena itu, dalam proses belajar mengajar musik di sekolah, siswa harus memperoleh pengalaman bermusik, yaitu melalui kegiatan mendengarkan, bermain musik, bernyanyi, membaca musik, dan bergerak mengikuti musik, sehingga siswa dapat memperoleh gambaran yang utuh dan menyeluruh tentang ungkapan lagu tersebut. Melalui pemahaman siswa terhadap unsur-unsur atau elemen-elemen musik seperti irama, melodi, harmoni, bentuk dan gaya musik, serta ekspresi sebagai bagian dari pengalaman bermusik, maka menanamkan pula kesadaran adanya kebutuhan musik dan bermusik bagi kehidupan siswa. Dengan demikian, masuknya pembelajaran musik di sekolah dasar, sekolah menengah pertama sampai sekolah menengah umum dalam kurikulum sekolah merupakan media dan 


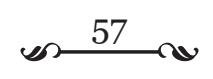

sarana pendidikan yang sebenarnya bertujuan sebagai sarana pembentukan perilaku, sikap, dan watak anak didik.

Mata pelajaran Pendidikan Seni Musik adalah salah satu mata pelajaran yang menuntut keterampilan seorang guru dalam mengorganisasi materi pembelajaran dan memberikan demonstrasi permainan lagu dan musik, serta menuntut kreativitas anak dalam belajar dan bermain musik. Hal ini mengindikasikan bahwa mata pelajaran Pendidikan Seni Musik dibelajarkan melalui teori dan praktek musik itu sendiri.

Dalam mencapai suatu yang baik pasti ditemui kendala dan permasalahan yang merintangi tercapainya tujuan kita. Pendidikan seni musik di sekolah dasar juga memiliki banyak kendala. Kendala yang muncul dapat dilihat dari tiga aspek. Pertama, aspek anak, kendala yang dihadapi dilihat dari segi anak biasanya berasal dari minat anak terhadap metode pendidikan seni musik yang didapatkannya. Kejadian ini kerap terjadi terutama bagi anak yang terlibat dalan pendidikan seni musik secara aktif, mungkin anak merasa bosan karena ia tidak menemukan sesuatu yang menarik dan menyenangkan. Kedua, aspek guru, kendala yang dihadapi dilihat dari aspek guru adalah mengenai pembelajaran pendidikan seni musik yang diberikan oleh guru tersebut. Apakah sudah mengakomodir ketertarikan anak, menciptakan suasana yang menarik dan menyenangkan. Ketiga, aspek sarana dan prasarana, kendala yang dihadapi dilihat dari aspek sarana dan prasarana adalah minimnya sarana dan prasarana yang ada di sekolah. Kedudukan mata pelajaran musik yang bukan merupakan mata pelajaran pokok (sering sebagai ekstrakurikuler) sering dianggap kurang begitu bermanfaat, sehingga berakibat pada kurangnya antusias stakeholder pendidikan untuk memberikan fasilitas yang memadai yang mendukung mata pelajaran tersebut.

Bagi sebagian masyarakat dan para pemangku kebijakan, musik bukan merupakan sesuatu hal yang penting, musik hanyalah sebagai hiburan, musik hanyalah pengisi waktu bagi anak-anak. Musik tidak akan memberikan kontribusi untuk kehidupan masa datang, musik tidak akan memberikan sesuatu profesi yang menjanjikan. Bahkan di lingkungan sekolah pun masih banyak yang menganggap bahwa musik bukan suatu mata pelajaran yang begitu penting. Banyak guru dan orang tua anak, baik itu yang belajar di sekolah formal ataupun informal, yang memandang sebelah mata tentang pendidikan musik. Sehingga apabila anaknya memiliki kekurangan pada 


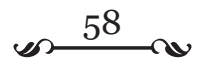

mata pelajaran tertentu, maka orang tua menganggap anaknya "kurang pandai”, tetapi apabila anak memiliki nilai bagus pada mata pelajaran seni musik orang tua menganggap hal tersebut bukan yang luar biasa.

Padahal apabila ditelaah lebih lanjut, menurut para ahli, pendidikan musik merupakan sarana yang paling efektif bagi pendidikan kreativitas. Pendidikan musik juga dapat menjadi sarana pendidikan afektif untuk menyalurkan emosi dan ekspresi anak. Selain itu, pendidikan musik dapat menjadi pendidikan keterampilan. Jadi, secara konseptual pendidikan musik sangat besar peranannya bagi proses perkembangan anak, terutama di sekolah dasar.

Selain itu, dalam kenyataannya sering dijumpai guru-guru musik di sekolah dasar masih cukup banyak yang berlatar belakang nonmusik. Keadaan tersebut berakibat bahwa pembelajaran musik yang seharusnya menjadi sarana untuk berolah rasa dan berolah keterampilan bermusik, pada kenyataannya hanya berupa pelajaran teori yang lebih mengarah dan menekankan ranah kognitif, sehingga ranah afektif dan ranah psikomotor menjadi terabaikan dan terlupakan.

Berdasarkan fenomena di atas, permasalahannya dapat diidentifikasi dengan proses pembelajaran Pendidikan Seni Musik yang terkesan seperti "hanya menyampaikan teori dan menyanyikan beberapa lagu, setelah itu pulang". Lalu, bagaimana seorang guru dapat menciptakan pembelajaran pendidikan seni musik secara kreatif dan menyenangkan bagi anak, serta berujung pada peningkatan minat, krativitas, dan semangat belajar perserta didik terhadap mata pelajaran seni musik masih terabaikan.

Merujuk pada permasalahan yang diidentifikasi di atas, dapat dirumuskan permasalahannya sebagai berikut: (1) bagaimana peran seorang guru seni musik dalam proses pembelajaran di sekolah dasar, (2) bagaimana langkah-langkah seorang guru seni musik di sekolah dasar untuk meningkatkan profesionalitasnya dalam meningkatkan penguasaan keterampilan seni musik, dan (3) bagaimana implementasi pembelajaran melalui pendekatan pembelajaran musik berbasis kreativitas di sekolah dasar.

\section{B. Pembahasan}

Musik merupakan karya cipta manusia memakai medium bunyi untuk 
menikmatinya. Musik hadir dalam bentuk kesatuan irama, nada, ritme, notasi, melodi, harmoni, bentuk dan gaya, serta ekspresi. Musik itu sendiri meliputi tidak hanya instrumen saja, tetapi juga vokal. Hal ini berarti ketika seseorang mengetahui cara memainkan musik, belum dapat dikatakan sebagai pemusik apabila ia tidak memahami teknik vokal, demikian pula sebaliknya (Rouget, 1980: 73). Seorang komponis Honggaria, Zaltan Kodaly (1882-1967) berpendapat: "Tidak ada anak yang tidak mempunyai kemampuan musikal. Yang sering terjadi adalah kemampuan itu tidak dikembangkan".

Musik mempunyai estetika yang tinggi dan mengundang respon dari orang yang mendengarnya. Hal ini dikarenakan musik melibatkan respon emosi simpatik (sympathetic emotional responsiveness). Tidak mengherankan jika musik dapat membuat suasana menjadi sedih atau gembira ketika sebuah musik dimainkan karena musik mempunyai sifat melibatkan sympathetic emotional responsiveness (Brocklehurst, 1971: 42).

Dalam rangka mencapai tujuan pendidikan nasional, pembelajaran seni musik sangat memberi kontribusi yang besar dalam pembentukan manusia Indonesia seutuhnya. Pembelajaran seni musik merupakan pembelajaran yang memberikan kemampuan mengekspresikan dan mengapresiasikan seni secara kreatif untuk pengembangan kepribadian siswa dan memberikan sikap-sikap atau emosional yang seimbang. Seni musik membentuk disiplin, toleran, sosialisasi, sikap demokrasi yang meliputi kepekaan terhadap lingkungan. Dengan kata lain, pembelajaran seni musik merupakan materi yang memegang peranan penting untuk membantu pengembangan individu siswa yang nantinya akan berdampak pada pertumbuhan akal, pikiran, sosialisasi, dan emosional.

Terdapat unsur-unsur musik yang perlu ditekankan dalam pembelajaran musik, diantaranya adalah:

1. Bunyi, merupakan unsur musik dalam membuat karya musik, dalam bunyi kita menemukan nada (tinggi rendahnya bunyi), melodi (rangkain nada-nada) .

2. Irama, gerak musik yang berjalan teratur yang tidak tampak dalam lagu tetapi dapat dirasakan setelah lagu itu dialunkan. Irama juga mempunyai istilah lain yaitu ritme. Irama atau ritme adalah pengaturan bunyi dalam waktu. Ritme itu sendiri merupakan suatu bagian dari melodi atau lagu. Di dalam suatu irama terdapat notasi irama berbentuk not dan tanda diam, tempo yang merupakan pernyataan cepat lambat dalam lagu. 


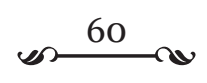

3. Tempo dapat diartikan sebagai ketukan konstan yang memikat bunyi menjadi satu kesatuan detak. Dalam hal ini tempo dapat diartikan sebagai rata-rata satuan waktu pada saat sebuah musik dimainkan yang menggambarkan kecepatan musik tersebut. Dalam bermain musik kita jangan sampai mendahului atau melebihi lambat dari tempo.

4. Timbre disebut dengan warna suara. Dalam hal ini timbre sangat dipengaruhi oleh sumber bunyi dan cara menggetarkan atau membunyikannya.

5. Dinamika merupakan aspek musik yang terkait dengan tingkat kekerasan bunyi. Adapun simbol musik yang menjelaskan tentang dinamika musik seperti piano (lembut) dan forte (keras).

6. Pada tingkat permualaan sebaiknya dipakai alat-alat yang mudah dimainkan. Pada umumnya alat-alat ritmis didahulukan dari pada alat-alat melodis, jadi permainannya bersifat permainan irama, lalu permainan irama secara bertahap dan dapat diberikan permainan melodis. Dalam hal ini sebaiknya instrumen yang digunakan adalah alatalat musik melodis yang dipukul (Djohan 2005: 199).

Beberapa manfaat mengajarkan musik pada anak sejak dini adalah sebagai berikut:

a. Membangun kepekaan anak terhadap keindahan, khususnya suara;

b. Melatih keseimbangan mental;

c. Pertumbuhan emosional menjadi optimal;

d. Mencerdaskan otak anak;

e. Sarana menyalurkan rasa ingin tahu secara positif;

f. Membentuk rasa percaya diri yang kuat;

g. Sarana menggali potensi dan bakat musik dalam diri anak;

h. Anak memiliki kepekaan yang jauh lebih besar;

i. Membantu anak menjadi diri pribadi yang mandiri;

j. Memperbaiki kontrol motoris;

k. Meningkatkan kemampuan bahasa dan berbicara;

1. Mengontrol emosional dan perkembangan sosial anak (Pramono, 2015: 158-159). 


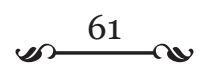

\section{Kreativitas dalam Pembelajaran}

Kreativitas merupakan kemampuan seseorang untuk menghasilkan pekerjaan yang baru dan tepat guna. Selain itu, kreativitas merupakan suatu hal yang penting baik ditinjau dari aspek individual maupun sosial, dan dapat dimunculkan dengan mempelajari karya cipta yang sudah ada sebelumnya, untuk kemudian diperbaharui sehingga menghasilkan karya cipta baru (Sternberg, 1999: 3).

Kreativitas juga dapat dimunculkan dengan mempelajari karya cipta yang sudah ada sebelumnya, untuk kemudian diperbaharui sehingga menghasilkan karya cipta baru. Hal ini dapat dilihat dari perjalanan perkembangan kreativitas Mozart yang mempunyai karya-karya terkenal sampai ke seluruh penjuru dunia. Di awal kariernya sebagai pemusik, ternyata Mozart banyak belajar dari karya Johann Christian Bacht yang merupakan anak dari Johan Sebastian Bacht. Mozart terinspirasi musik Johan Sebastian Bacht dan akhirnya mampu membuat karya musik baru yang berbeda dari karya yang menginspirasinya. Hal ini dapat terjadi karena adanya unsur kreativitas Mozart yang akhirnya membawanya kepada ketenaran sebagai musikus klasik dunia (Sternberg, 1999: 235-236).

Pendapat lain tentang kreativitas adalah kemampuan untuk melihat atau memikirkan hal-hal yang luar biasa, yang tidak lazim, memadukan informasi yang tampaknya tidak berhubungan dan mencetuskan solusi-solusi baru atau gagasan-gagasan baru, yang menunjukkan kelancaran, kelenturan, dan orisinalitas dalam berpikir (Munandar, 1999: 168).

Proses pembelajaran kreativitas pada dasarnya adalah untuk mengembangkan berbagai alternatif pemikiran atau cara dalam mengatasi berbagai permasalahan sesuai dengan apa yang ada dibenaknya. Munandar (1999: 21) mengemukakan bahwa proses kreatif meliputi empat tahap, yaitu (1) persiapan; (2) inkubasi; (3) iluminasi; (4) verifikasi. Munandar (Muhammad, 2010: 182) juga menyebutkan ciri-ciri dari kreativitas yakni kelancaran, fleksibilitas, orisinalitas, elaborasi, atau perincian.

Menurut Elaine B. Johnson (Asmani, 2011: 138) kreativitas adalah berkah khusus bagi sejumlah kecil orang-orang yang luar biasa. Orang kreatif lahir dilengkapi kekuatan untuk membayangkan kemungkinankemungkinan di luar yang bisa dibayangkan oleh orang biasa, dan melihat hal-hal yang tidak dilihat orang kebanyakan. Orang kreatif, yang terlahir untuk menulis puisi, melukis lukisan dinding, menciptakan tarian balet, dan 


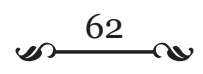

menggubah musik adalah orang-orang yang luar biasa berbakat, brilian, dan penuh inspirasi.

Kreativitas dalam pembelajaran musik sangat diperlukan untuk mendapatkan pengetahuan, pemahaman, dan penguasaan musik yang optimal karena musik itu sendiri memiliki banyak dimensi kreatif. Sebagai contoh, dalam musik terdapat analogi melalui persepsi, visual, auditori, antisipasi, pemikiran induktif-deduktif, memori, konsentrasi, dan logika. Dalam musik juga dapat dibedakan serta dipelajari cepat-lambat, tinggirendah, keras-lembut yang berguna untuk melatih kepekaan terhadap stimuli lingkungan. Selain itu, musik juga berpengaruh sebagai alat untuk meningkatkan dan membantu perkembangan kemampuan pribadi dan sosial (Djohan, 2005: 141).

Alasan lain mengapa dibutuhkan kreativitas dalam pembelajaran musik karena aktivitas musik itu sendiri justru banyak melibatkan kegiatan yang mendorong terjadinya penciptaan yang membutuhkan kreativitas (Djohan, 2005: 142). Dengan demikian, setiap anak perlu diberikan kesempatan seluasluasnya untuk mencari pengalaman-pengalaman bermusik. Melalui musik seorang anak dapat mengembangkan imaji dan kreasi, mengkontribusikan ekspresi diri, serta kreativitas. Selain itu, musik juga dapat merangsang kreativitas dan individualitas. Hal inilah yang menjadi alasan mengapa musik disejajarkan dengan disiplin dasar lainnya dan penting untuk dihadirkan di dalam pendidikan (Djohan, 2005: 211-212).

Semua orang yakin bahwa guru memiliki andil yang sangat besar terhadap keberhasilan pembelajaran di sekolah. Guru sangat berperan dalam membantu perkembangan anak untuk mewujudkan tujuan hidupnya secara optimal. Untuk mengungkap dan menemukakan langkah-langkah yang harus dilewati oleh seorang guru dalam rangka meningkatkan mutu, kualitas pendidikan dan dalam rangka meningkatkan profesionalitas seorang guru dapat dilihat dari beberapa aspek diantaranya:

\section{a. Personality Guru}

Minat, bakat, kemampuan, dan potensi-potensi yang dimiliki oleh anak tidak akan berkembang secara optimal tanpa bantuan guru. Dalam kaitan ini guru perlu memperhatikan anak secara individual, karena satu anak dengan anak yang lain memiliki perbedaan yang sangat mendasar. Guru juga harus berpacu dalam pembelajaran, dengan memberikan kemudahan belajar bagi seluruh anak, agar dapat mengembangkan 


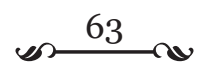

potensinya secara optimal. Dalam hal ini guru harus kreatif, profesional, dan menyenangkan dengan memposisikan diri sebagai berikut: (1) orang tua yang penuh kasih sayang pada anaknya, (2) teman, tempat mengadu, dan mengutarakan perasaan bagi anak, (3) fasilitator yang selalu siap memberikan kemudahan, melayani pesera doidik sesuai dengan minat, kemampuan, dan bakatnya, (4) memberikan sumbangan pemikiran kepada orang tua untuk dapat mengetahui permasalahan yang dihadapi anak dan membantu pemecahannya, (5) memupuk rasa percaya diri, berani bertanggung jawab, (6) membiasakan anak untuk saling berhubungan (bersilaturahmi) dengan orang lain secara wajar, (7) mengembangkan proses sosialisasi yang wajar antar anak, orang lain, dan lingkungannya, (8) mengembangkan krativitas, (9) menjadi pembantu ketika diperlukan.

Untuk memenuhi tuntutan di atas, guru harus mampu memaknai pembelajaran sebagai ajang pembentukan kompetensi dan perbaikan kualitas pribadi anak. Untuk kepentingan tersebut, dengan memperhatikan kajian Pullias dan Young (1988), serta Yelon dan Weinstein (1997) dalam Mulyasa (2007: 37), dapat diidentifikasikan sedikitnya 19 peran guru, guru sebagai pendidik, pengajar, pembimbing, pelatih, penasehat, pembaharu (innovator), model dan teladan, pribadi, peneliti, pendorong kreativitas, pembangkit pandangan, pekerja rutin, pemindah kemah, pembawa ceritera, aktor, emansipator, evaluator, dan sebagai kulminator. Begitu banyak yang harus dilakukan guru dalam memaknai pembelajaran dan secara tak langsung akan meningkatkan profesionalitas dan potensi yang dipunyai guru. Untuk memenuhi semua peran yang harus dimiliki oleh guru tentu bukan kerja yang mudah. Seorang guru butuh kerja keras untuk mewujudkan atau memenuhi tuntutan untuk meningkatkan profesionalitas.

Pada akhir-akhir ini, pemerintah dalam hal ini Pendidikan Nasional menggalakkan suatu program sertifikasi, yaitu sebuah program penilaian terhadap standar profesionalisasi guru yang dikenal dengan sertifikasi guru. Secara garis besar guru harus menyiapkan hal-hal yang dipersyaratkan dalam sertifikasi seorang guru, seperti portofolio aktivitas guru yang telah dilakukan dalam rangka meningkatkan wawasan dan pemahaman guru terhadap kependidikan, proses pembelajaran yang telah dilakukan oleh guru (Silabus, SAP, RPP) untuk proses pembelajaran, dan aktivitas-aktivitas lain yang dilakukan untuk lebih memahami tentang 


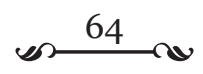

seluk-beluk pendidikan, bahkan sampai ke pelatihan-pelatihan, guna meningkatkan kemampuan dan kompetensi guru tersebut.

Guru dituntut untuk kreatif dalam menggunakan metode dan media yang bervariasi, memodifikasi dan memperkaya bahan pembelajaran, mengembangkan situasi belajar yang memungkinkan setiap anak bekerja dengan kemampuan masing-masing pada setiap materi serta mengusahakan keterlibatan anak dalam berbagai kegiatan pembelajaran. Menurut Iskandar Agung (2010: 68), pengembangan strategi kreativitas guru paling sedikit meliputi cara-cara: 1) memperluas wawasan dan pengetahuan, 2) mengembangkan komunitas kelas, 3) mengembangkan lingkungan fisik pembelajaran, 4) mengembangkan sikap keterbukaan, 5) optimalisasi pemanfaatan teknologi pembelajaran, 6) memunculkan tantangan, dan 7) mengembangkan alat evaluasi.

Kompetensi guru profesional adalah gabungan dari empat aspek, yaitu; komunikator, kurikulum, strategi belajar, dan assessment yang jitu. Rusydie (2011: 104-105) mengungkapkan tentang beberapa potensi yang harus dimiliki oleh guru profesional, yakni: 1) memiliki kemampuan intelektual yang memadai, 2) memiliki kemampuan untuk memahami visi dan misi pendidikan, 3) memiliki keahlian dalam mentransfer ilmu pengetahuan atau menguasai metodologi pembelajaran dengan baik, 4) memiliki pemahaman yang baik tentang konsep perkembangan siswa, 5) memiliki kemampuan mengorganisir atau mengelola kelas, dan 6) memiliki kreativitas dan naluri seni dalam mendidik sehingga siswa dapat mengikuti kegiatan belajar dengan baik. Kelas yang baik bukan cuma dilihat dari urusan kurikulum, sumber belajar, dan fasilitas, tapi juga hubungan antar manusianya. Mengajar sesuai dengan kurikulum memang penting, apalagi jika ditambah dengan guru yang mau melakukan eksplorasi terhadap kurikulum 2013. Kurikulum 2013 berguna sebagai peta, kreativitas guru adalah kekuatan untuk menapakinya.

Pada pembelajaran seni, budaya dan keterampilan khususnya mata pelajaran pendidikan seni musik dapat dilakukan guru dengan menggunakan beberapa metode dan pendekatan-pendekatan yang akan menghantarkan anak kepada pembelajaran pendidikan seni musik yang menyenangkan, menarik, dan bermakna bagi anak. Dengan memperhatikan personality guru yang dijabarkan di atas, guru harus mempersiapkan secara efisien dan efektif segenap kemampuan pribadi dan 


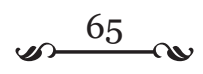

kemampuan akademis. Layaknya seorang guru yang akan memberikan pembelajaran pendidikan seni musik, sudah tentu harus mengerti akan basic musik, baik itu mengenai vokal maupun mengenai permainan atau praktek musik itu sendiri.

Pada pembelajaran pendidikan seni musik di sekolah dasar kemampuan guru tidak dituntut harus mahir memainkan seluruh alat musik secara profesional layaknya seorang pekerja seni atau ilmu seni murni (fine art) ataupun harus menjadi seorang pakar seni baru bisa membelajarkan seni musik, dan tidak harus menjadi vokalis terkenal dalam menyanyikan lagu-lagu yang sulit, akan tetapi guru lebih diutamakan berperan sebagai seorang akademisi yang akan memberikan pengalaman musik sesuai dengan kehidupan anak dalam keseharian mereka. Dengan kata lain guru memposisikan dirinya sebagai ilmu seni terapan (application art).

Pada proses pembelajaran yang diberikan atau ditransfer oleh guru harus disesuaikan dengan tingkat pernguasaan dan perkembangan siswa. Selain memenuhi 19 peran guru yang dikemukakan oleh Yellon dan Weinstein (1997), seorang guru juga harus memperhatikan tingkat perkembangan anak. Apa yang sedang digemari dan berada pada tingkatan apa pola pikir anak pada saat dilakukan proses pembelajaran, serta apa yang menjadi proritas perkembangan psikologis seorang anak. Pada uraian di atas telah dikemukakan bahwa seorang guru harus memperhatikan anak secara individual. Hal ini menyangkut tingkat perkembangan, permasalahan yang sedang dihadapi dan lain sebagainya. Berikut ini akan dikemukakan pendapat para pakar dalam perkembangan anak:

\section{1) Teori Piaget.}

Piaget mengatakan bahwa belajar merupakan aktivitas yang melibatkan proses berpikir yang komplek. Proses belajar terjadi pengaturan antara stimulus yang diterima dan dimiliki yang dibentuk dalam pikiran seseorang berdasarkan pemahaman dan pengalaman sebelumnya.

Kesiapan anak belajar di SD menurut Piaget adalah bila anak sudah mencapai tingkat berpikir operasional konkret (usia 6/711/12 tahun). Pada tahap berpikir konkret ini anak sudah mampu memikirkan sesuatu (lebih dari satu beda) pada saat bersamaan bila 


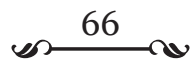

yang difikirkannya bersifat nyata/konkret (Suprijono, 2009: 23).

\section{2) Jerome Bruner}

Menurut Bruner, kesiapan belajar merupakan peristiwa aktif dan tidak bersifat pasif dalam mempengaruhi lingkungan belajar. Peristiwa aktif yang merupakan tanda kesiapan belajar ditandai dengan perkembangan berfikit seseorang ditentukan oleh cara melihat lingkungan, yaitu melalui tiga tahap berikut: 1) Tahap enaktif, yaitu anak melakukan aktifitas dalam upaya memahami lingkungan sekitarnya dengan pengetahuan motorik. Sebagai contoh, mengenal sesuatu melalui digigit, disentuh atau dipegang; 2) Tahap ikonik, yaitu seseorang memahami suatu obyek/dunianya melalui gambargambar dan visualisasi verbal, dan 3) Tahap simbolik, yaitu seseorang mampu mengemukakan ide atau gagasan abstrak dipengaruhi oleh kamampuan bahasa dan logika melalui simbol-simbol bahasa, logika, matematika dan sebagainya (Suprijono, 2009: 24).

3) Teori Vygotsky.

Dia mengatakan bahwa jalan pikiran seseorang harus dimengerti dari latar sosial budaya dan sejarahnya, artinya memahami jalan pikiran seseorang adalah dari asal usul tindakan sadarnya, dari interaksi sosial yang dilatari oleh sejarah hidupnya. Menurut Vygotsky, bahasa adalah merupakan aspek sosial. Pembicaraan egosentrik merupakan permulaan dari pembentukan inner speech (kemampuan bicara yang pokok) yang akan digunakan sebagai alat dalam berpikir (Suprijono, 2009: 32). Pertumbuhan berpikir anak bersifat context dependent atau tidak dapat dipisah-pisah dari kontek sosial.

Implikasi pertumbuhan berpikir anak usia sekolah dasar ini menuntut agar dalam pembelajaran dilakukan sebagai berikut:

1) Dalam membahas materi pelajaran dibawa ke dalam suasana konkret dan kalau dapat dibawa ke dalam situasi nyata, sesuai dengan pendapat Bruner cara belajar anak dengan memberi kesempatan pada anak menemukan konsep dan pemahaman konsep dengan cara enaktif, ikonik dan simbolik.

2) Bila dalam pembelajaran tidak dapat dibawa ke dalam realita yang sebenarnya, maka guru harus berupaya mengganti dengan pengganti suasana yang nyata, berupa penggunaan media pembelajaran. Sedapat 


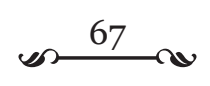

mungkin guru harus berupaya agar dalam proses pembelajaran anak dapat memperoleh berbagai pengetahuan dan keterampilan melalui interaksi sosial atau sumber-sumber sosial di luar dirinya.

\section{b) Desain Pembelajaran}

Esensi desain pembelajaran hanyalah mencakup empat komponen, yaitu siswa, tujuan, metode, dan evaluasi serta analisis topik. Empat komponen tersebut dipengaruhi oleh teori belajar dan pembelajaran, sedangkan analisis topik merupakan desain pembelajaran yang dihasilkan dari disiplin ilmu tertentu. Untuk mengetahui apa sebenarnya desain pembelajaran dengan mengacu kepada pendapat Rothwell dan Khazanas, 1992 dalam Dewi Salma Prawiradilaga (2008: 15) mengemukakan bahwa desain pembelajaran merupakan kegiatan merumuskan desain pembelajaran terkait dengan peningkatan mutu kinerja seseorang dan pengaruhnya bagi organisasi. Bagi mereka peningkatan kinerja berarti peningkatan kinerja organisasi. Desain pembelajaran melakukan hal tersebut melalui suatu model kinerja manusia.

Berdasarkan teori kognitif, teori pemrosesan informasi, serta teori komunikasi, dapat dikembangkan lima prinsip utama desain pembelajaran:

1) Prinsip kesiapan dan motivasi; Prinsip ini mengatakan bahwa dalam kegiatan pembelajaran, siswa yang memiliki kesiapan, seperti kesiapan mental, fisik, dan motivasi tinggi, hasil belajarnya akan lebih baik.

2) Prinsip penggunaan alat pemusat perhatian; Prinsip ini mengatakan bahwa jika dalam proses belajar perhatian siswa terpusat pada pesan yang dipelajari, maka proses dan hasil belajar akan semakin baik.

3) Prinsip parisipasi aktif siswa; Prinsip ini meliputi aktivitas, kegiatan, atau proses mental, emosional, maupun fisik.

4) Prinsip umpan balik; Umpan balik adalah informasi yang diberikan kepada siswa mengenai keberhasilan atau kekurangannya dalam belajar.

5) Prinsip pengulangan; Pengulangan diperlukan dalam proses penguasaan materi pembelajaran agar informasi atau pesan pembelajaran dapat bertahan lama dan tidak mudah dilupakan (Asmani, 2011: 150-153). 


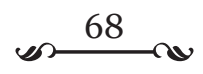

Pembelajaran musik memang membutuhkan pemahaman guru mengenai dasar-dasar musik dan mampu memberikan pengalaman musik agar siswa bisa mengekspresikan dan menyanyikan lagu-lagu sesuai dengan tuntutan kurikulum. Seandainya kemampuan guru terbatas dalam bidang musik, maka guru bisa menggunakan berbagai media pembelajaran seperti media audio. Untuk menyanyikan dan menghafalkan lagu-lagu wajib dan lagu anak-anak guru bisa menyiapkan tape recorder dan memperdengarkan lagu tersebut kepada siswa. Setelah itu perlahan-lahan siswa disuruh untuk mengikuti lagu tersebut sampai mereka hafal irama dan lirik lagu tersebut. Disamping itu, guru melatihkan solmisasi (do, re, mi, fa, so, la, si, do) dengan ketepatan nada yang diucapkan. Latihan ini dilakukan secara berulang-ulang sehingga nada-nada yang diucapkan dan dibaca oleh anak dapat lengket di dalam pikiran mereka. Setelah itu baru diajarkan cara membuat ketukan sesuai dengan tempo yang dituliskan dipartitur lagu.

Sesuai dengan tingkat perkembangan anak sekolah dasar yang kecenderungan masih menganut pola pikir konkret dan masih dalam taraf belajar sambil bermain, maka hal ini menjadi bahan untuk guru dalam membelajarkan pendidikan seni musik sesuai dengan SK, KD, dan indikator kurikulum untuk membuat desain yang menyenangkan dan bermakna bagi anak, dan menggunakan berbagai strategi pembelajaran yang merangsang anak untuk mengikuti pembelajaran. Caranya, dengan menyuruh anak melakukan gerakan, dan ekspresi mereka dalam bernyanyi, serta guru harus menerapkan metode pembelajaran berbasis PAIKEM. Guru berusaha mengkondisikan pembelajaran yang aktif, kreatif, inovatif, dan menyenangkan.

Pendidikan seni, budaya, dan keterampilan memiliki sifat multilingual, multidimensional, multikultural. Multilingual bermakna pengembangan kemampuan mengekspresikan diri secara kreatif dengan berbagai cara dan media seperti: bahasa rupa, bunyi, gerak, peran, dan berbagai perpaduannya. Multidimensional bermakna pengembangan beragam kompetensi meliputi konsepsi (pengetahuan, pemahaman, analisis, evaluasi), apresiasi, dan kreasi dengan cara memadukan secara harmonis unsur estetika, logika, kinestetika, dan etika. Sifat Multikultural mengandung makna pendidikan seni menumbuhkembangkan kesadaran dan kemampuan apresiasi terhadap beragam budaya nusantara dan 


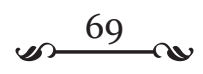

mancanegara. Hal ini merupakan wujud pembentukan sikap demokratis yang memungkinkan seseorang hidup secara beradab serta toleran dalam masyarakat dan budaya majemuk.

Pendidikan seni, budaya, dan keterampilan memiliki peranan dalam pembentukan pribadi anak yang harmonis dengan memperhatikan kebutuhan perkembangan anak dalam mencapai multi kecerdasan yang terdiri atas kecerdasan intrapersonal, interpersonal, visual spasial, musikal, linguistik, logik matematik, naturalis, serta kecerdasan adversitas, kecerdasan kreativitas, kecerdasan spritual, kecerdasan moral, dan kecerdasan emosional.

Mata pelajaran Seni, Budaya, dan Keterampilan meliputi aspekaspek sebagai berikut:

1. Seni rupa mencakup pengetahuan, keterampilam, dan nilai-nilai dalam menghasilkan karya seni, berupa: lukisan, patung, ukiran, cetak-mencetak, dan sebagainya.

2. Seni musik, mencakup kemampuan untuk menguasai olah vokal, memainkan alat musik, apresiasi karya musik.

3. Seni tari, mencakup keterampilan gerak berdasarkan olah tubuh dengan dan tanpa rangsangan bunyi, apresiasi terhadap gerak tari.

4. Seni drama, mencakup keterampilan pemen

5. tasan dengan memadukan seni musik, tari, dan peran.Keterampilan, mencakup segala aspek kecakapan hidup (life skills) yang meliputi keterampilan personal, keterampilan sosial, keterampilan vokasional, dan keterampilan akademik.

\section{c. Proses Pembelajaran}

Kurikulum 2013 mengisyaratkan bahwa proses pembelajaran yang dilaksanakan di kelas awal sekolah dasar menggunakan pendekatan tematik, tanpa melihat adanya batasan yang jelas di antara mata pelajaran-mata pelajaran yang diberikan kepada anak, dan tidak mengenal batasan-batasan waktu antara satu mata pelajaran dengan mata pelajaran lain. Pendekatan Tematikjuga menggunakan tema sebagai fokus pembelajaran, dan jaringan tema sebagai keterkaitan fokus dengan mata pelajaran lain yang mendukung tema yang diberikan kepada anak.

Seorang guru dalam melaksanakan proses pembelajarannya di 


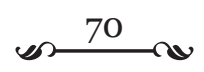

kelas harus mempunyai perencanaan yang jelas dan terorganisir, agar bisa menjalankan tugasnya sebagai transformator dan fasilitator dapat terlaksana dengan baik di depan kelas, sehingga tercipta pembelajaran yang bermakna dan menyenangkan bagi anak. Perencanaan yang harus dimiliki oleh seorang guru berbentuk RPP yang di dalamnya tertuang strategi pembelajaran, metode pembelajaran, pendekatan-pendekatan yang digunakan dalam proses pembelajaran, serta media-media untuk kelancaran proses pembelajaran. RPP juga berisikan Standar Kompetensi, Kompetensi Dasar. Semua itu diikuti dengan perumusan indikator yang mengisyaratkan kepada guru tentang kemampuan yang harus dikuasai oleh anak.

Sebagai contoh pada kelas $4 \mathrm{SD}$, seharusnya indikator dirumuskan berdasarkan kata kunci yang ada pada kompetensi dasar yang dituntut, dimana siswa baru belajar pada tingkat menulis atau menyadur lirik lagu anak-anak dan lagu wajib dengan teks yang pendek dan sederhana. Dan Kompetensi Dasar yang ada, anak belum dituntut untuk membuat lirik lagu karena mereka baru berada pada tahap belajar menulis.

Untuk mengetahui sejauh mana penguasaan anak terhadap materi yang diberikan oleh guru, banyak hal yang bisa dilakukan seperti halnya apa yang terdapat pada unsur-unsur assesmen atau penilaian proses. Guru bisa melakukan penilaian dengan melakukan dan memperhatikan portofolio anak, wawancara, anekdotal record, matrik penguasaan siswa. Assesmen ini dilakukan dengan mengacu kepada tiga ranah, yaitu: kognitif, afektif, dan psikomotor. Dan pada tingkat yang lebih tinggi seorang guru harus membiarkan anak menilai kerja mereka sendiri, dan menentukan nilai apa yang semestinya mereka dapatkan (penilaian diri sendiri).

Pemakaian dan penggunaan media pembelajaran pada mata pelajaran pendidikan seni musik khususnya, bisa dilakukan dengan cara memanfaatkan media-media yang dekat dengan diri anak. Seperti, tepuk tangan, hentakan kaki, bernyanyi, gerakan tubuh, serta memanfaatkan peralatan-peralatan bekas, seperti: gelas, botol dan lain sebagainya. Media ini diorganisir sedemikian rupa sehingga anak dapat memperolehnya dengan mudah dan sekaligus membuat mereka menyenangi dan menyukai kegiatan yang dilakukan, dan pada akhirnya mereka mau menerima apa materi yang diberikan oleh guru. 


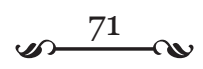

Mengacu kepada tujuan dan ruang lingkup yang dijelaskan dalam Kurikulum 2013, guru seharusnya memberikan pengalaman kepada anak untuk dapat menguasai oleh vokal dengan cara memperhatikan langkah-langkah, seperti 1) mengambil posisi berdiri tegak dan rilek; 2) melakukan pemanasan (warming up) dengan mengambil nafas. Anak dipandu untuk mengambil nafas yang benar dalam bernyanyi dengan cara menarik nafas panjang, lalu ditahan beberapa detik (maksimal 30 detik) dan membuangnya dengan cara perlahan-lahan; 3) membunyikan satu buah nada yang standar dengan membunyikan satu nada pada alat musik seperti nada "c" atau nada do. Anak disuruh untuk menyuarakan nada "do" secara bersama-sama sampai suara yang dikeluarkan sama dengan bunyi yang dikeluarkan alat musik; 4) menggunakan pernafasan diagfragma (pernafasan perut). Setelah latihan ini benar-benar sesuai dan pas, serta diulang beberapa kali, dilanjutkan dengan latihan beberapa tingkatan nada dalam solmisasi seperti do, re, mi, fa, sol, la, si, do; 5) menyuarakan vokal A, I, U, E, dan O. Hal ini akan menghasilan pengucapan yang benar mengenai artikulasi sebuah kata-kata lagu; 6) pada tahap terakhir anak membaca notasi musik yang dipandu oleh guru dengan cara membaca notasi sepotong-sepotong dan dilakukan berulang-ulang, sehingga mereka bisa membaca notasi musik sambil menghafal. Dan pada bahagian akhir latihan barulah membaca notasi musik secara utuh, sambil diselingi dengan menyanyikan kata-kata atau lirik lagu tersebut.

\section{Implementasi Seni Musik di Sekolah Dasar}

Tujuan pengajaran musik di SD harus dijabarkan menjadi beberapa tujuan instruksional umum (TIU) sesuai dengan pengelompokkan unsurunsur musik yang esensial, yaitu irama, melodi, harmoni, bentuk/struktur lagu, dan ekspresi. Tujuan instruksional umum untuk pengajaran musik di SD dapat dirumuskan sebagai berikut:

a. Siswa dapat memiliki pengetahuan tentang irama, merasakan irama melalui pengalaman dan penghayatan musik, mempunyai bayangan penginderaan gerak irama, membuat gerak irama, membuat pola-pola irama sederhana, dan membaca notasi pola-pola irama dengan benar.

b. Siswa dapat memiliki pengetahuan tentang melodi, merasakan melodi melalui pengalaman dan penghayatan musik, mempunyai bayangan 


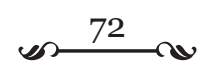

penginderaan gerak melodi, membuat pola-pola melodi sederhana, dan membaca notasi melodi dengan benar.

c. Siswa dapat memiliki pengetahuan tentang harmoni, merasakan harmoni melalui pengetahuan dan penghayatan musik, mempunyai bayangan penginderaan gerak harmoni, mengiringi lagu-lagu sederhana dengan alat musik harmoni sederhana, dan membaca notasi harmoni dengan sederhana.

d. Siswa dapat memiliki pengetahuan tentang bentuk/struktur lagu melalui pengalaman dan penghayatan musik, mempunyai bayangan penginderaan bentuk-bentuk lagu, dan mengarang lagu-lagu sederhana.

e. Siswa dapat pengetahuan tentang ekspresi, merasakan ekspresi melalui pengalaman dan penghayatan musik, mempunyai penginderaan bermacam tingkat ekspresi, menyanyikan atau memainkan lagu-lagu dengan tingkat ekspresi yang tingi.

Musik dapat membantu anak untuk mampu berekspresi lebih baik, melatih kepekaan mereka terhadap seni (khususnya musik) dan lingkungan, meningkatkan kecerdasan otak, meningkatkan daya pikir, mengembangkan kreativitas, dan menumbuhkan rasa percaya diri untuk tampil di muka umum (Pramono, 2015: 157). Mengajarkan musik pada anak sedini mungkin memiliki manfaat yang jauh lebih besar daripada mengenalkan musik pada saat anak menginjak usia di atas 10 tahun.

Musik anak harus sesuai dengan perkembangan fisik yang mampu menjadikan dirinya sebagai media pengungkapan perasaan, pikiran, isi hati anak. Pemilihan alat musik pun harus disesuaikan dengan usia anak. Misalnya, pada usia 6-7 tahun pada kelas rendah sekolah dasar, anak bisa mulai diperkenalkan dengan alat musik seperti piano, biola, gitar, atau drum. Karena pada usia ini otot-otot tangan dan kaki anak sudah lebih kuat daripada usia balita. Jika anak berminat dengan alat musik tiup, saat anak berusia 8-9 tahun atau tingkat sedang sekolah dasar, maka anak bisa mulai diperkenalkan pada seruling. Ketika usianya sudah cukup dan kemampuannya berkembang, anak bisa melanjutkan dengan alat musik tiup lain seperti flute, saksofon, ataupun klarinet.

Karakter musik anak seyogyanya dapat ditemukan tidak hanya pada semua aspek musik tetapi juga seperti; aspek bunyi, nada, ritme, tempo dan dinamik serta ekspresi dan bentuk musik. Selain itu seyogyanya musik anak mampu memberikan kesempatan bagi perkembangan kreativitas berpikir 


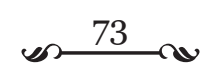

dan seni (rasa keindahan) anak serta dunia anak. Berikut ini karakteristik yang sebaiknya muncul dalam musik anak adalah: 1) musik sesuai dengan minat dan menyatukan dengan kehidupan anak sehari-hari; 2) ritme musik dan pola melodinya pendek sehingga mudah diingat, 3) nyanyian atau lagu tersebut juga harus mengandung unsur musik lainnya, dan 4) melalui musik anak diberi kesempatan pula untuk bergerak melalui musik.

\section{Kreativitas Pembelajaran Seni Musik di Sekolah Dasar}

Kreativitas pembelajaran melalui pendekatan PAIKEM dapat berjalan sebagaimana yang diharapkan yakni dengan mempertimbangkan beberapa aspek. John B. Biggs dan Ross Telfer (Asmani, 2011: 161) menyebutkan bahwa aspek-aspek tersebut merupakan aspek dari sebuah pembelajaran kreatif yang harus dipahami dan dilakukan oleh seorang guru yang baik dalam proses pembelajaran terhadap siswa. Aspek-aspek tersebut adalah sebagai berikut:

a. Memahami potensi siswa yang tersembunyi dan mendorongnya untuk berkembang sesuai dengan kecenderungan bakat dan minat mereka.

b. Memberikan kesempatan kepada siswa untuk belajar meningkatkan rasa tanggung jawab dalam melaksanakan tugas dan bantuan jika mereka membutuhkan.

c. Menghargai potensi siswa yang lemah/lamban dan memperlihatkan antuisme terhadap ide serta gagasan mereka.

d. Mendorong siswa untuk terus maju untuk mencapai sukses dalam bidang yang diminati dan penghargaan atas prestasi mereka.

e. Mengakui pekerjaan siswa dalam satu bidang untuk memberikan semangat pada pekerjaan berikutnya.

f. Menggunakan kemampuan fantasi dalam proses pembelajaran untuk membangun hubungan dengan realitas dan kehidupan nyata.

g. Memuji kindahan perbedaan potensi, karakter, bakat dan minat, serta modalitas gaya belajar individu siswa.

h. Mendorong dan menghargai keterlibatan individu siswa secara penuh dalam proyek-proyek pembelajaran mandiri.

i. Menyatakan kepada para siswa bahwa guru-guru merupakan mitra mereka dan mempunyai peran sebagai motivator dan fasilitator bagi siswa. 


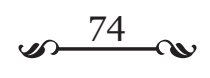

j. Menciptakan suasana belajar yang kondusif, bebas dari tekanan dan intimidasi, dalam usaha meyakinkan minat belajar siswa.

k. Mendorong terjadinya proses pembelajaran interaktif, kolaboratif, inkuiri, dan diskaveri, agar terbentuk budaya belajar yang bermakna (meaningful learning) pada siswa.

1. Memberikan tes/ujian yang bisa mendorong terjadinya umpan balik dan semangat/gairah pada siswa agar selalu ingin mempelajari materi lebih dalam (Asmani, 2011: 161-162).

Kreativitas dalam pembelajaran musik sangat diperlukan untuk mendapatkan pengetahuan, pemahaman dan penguasaan musik yang optimal karena musik itu sendiri memiliki banyak dimensi kreatif. Sebagai contoh, dalam musik terdapat analogi melalui persepsi, visual, auditori, antisipasi, pemikiran induktif-deduktif, memori, konsentrasi, dan logika.

Aktivitas musikal terfokus pada masalah-masalah dasar seperti cara berfikir atau "musik baru" yang memberikan kemungkinan mencapai tujuan metode dan komposional tertentu. Tujuan tersebut akan dicapai melalui pengembangan memori, improvisasi dan konsentrasi yang akan dipraktekkan kepada siswa. Musik kreatif ini dapat dilakukan dengan cara mengajak anak menemukan barang-barang baru untuk dijadikan sebagai alat musik, sehingga hal ini dapat memunculkan kreativitas mereka dalam bermusik. Misalnya, dengan menggunakan alat-alat di sekitar mereka seperti botol, tong, ember, bambu, mereka membuat alat musik kreatif dan memainkannya dengan kreativitas mereka pula.

Pada umumnya, pembelajaran musik secara konvensional, seperti hanya belajar menyanyikan lagu-lagu dari awal hingga akhir jam pelajaran atau hanya belajar teori-teori tentang musik tanpa mempraktekkannya, akan membuat anak tidak dapat memahami musik secara menyeluruh, tidak dapat mengaplikasikannya secara nyata, serta tidak akan menemukan bakat/ potensi musik mereka. Hal ini juga menimbulkan perbedaan antara minat siswa yang menggunakan unsur kreativitas dalam mengikuti pembelajaran musik dengan siswa yang diajarkan dengan metode konvensional dalam pembelajaran. Siswa yang mengikuti pembelajaran musik dengan menerapkan unsur kreativitas memiliki kemampuan untuk melihat atau memikirkan hal-hal yang luar biasa, yang tidak lazim, memadukan informasi yang tampaknya tidak berhubungan dan mencetuskan solusi-solusi baru atau gagasan-gagasan baru, yang menunjukkan kelancaran, kelenturan, dan 


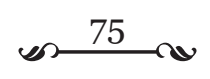

orisinalitas dalam berpikir. Selain itu, siswa merasa senang dan gembira karena diberi kebebasan berekspresi dan berkreasi melalui musik.

\section{Simpulan}

Dari pengamatan penulis, pembelajaran di SD belum menerapkan teori Piaget, Bruner dan Vygotsky. Guru cenderung membahas materi pembelajaran dengan menggunakan metode ceramah, hanya menyajikan teori tanpa praktek, serta hanya menyuruh anak menyanyikan lagu dari awal sampai akhir jam pelajaran tanpa menggunakan media pembelajaran. Ini berarti proses pembelajaran bersifat abstrak dan tidak sesuai dengan pertumbuhan berpikir anak yang bersifat konkret sehingga sangat sulit bagi anak untuk dapat mengerti, memahami dan pengaplikasikan materi pelajaran dalam kehidupan anak di luar sekolah. Hal ini menjadi penting untuk dilakukan oleh seorang guru, agar mengetahui dan dapat menciptakan pembelajaran yang mengesankan, kreatif dan menyenangkan bagi anak, sehingga tujuan pembelajaran dapat terlaksana dengan baik, efisien, dan efektif.

Realita pembelajaran di SD yang umumnya bersifat abstrak ini harus dirubah. Guru harus diberi wawasan, keterampilan dan kesadaran untuk merubah proses pembelajaran yang bersifat abstrak menjadi situasi konkret. Upaya ini dapat menjadikan proses pembelajaran berjalan lebih baik dan kualitas pencapaian hasil dapat lebih optimal, profesional, dan sesuai dengan standar minimal pembelajaran dan percepatan sertifikasi guru.

Guru-guru seni musik perlu mendapatkan pembinaan yang baik dan berkelanjutan agar dalam melaksanakan pembelajaran seni musik selalu memasukkan unsur kreativitas. Selain itu, setiap sekolah perlu menyediakan tempat dan waktu tersendiri bagi para siswa untuk belajar seni musik dengan lebih leluasa.

Guru harus mempunyai perencanaan yang matang, strategi pembelajaran, pendekatan-pendekatan, metode pembelajaran, dan evaluasi yang akan mengakomodir kompetensi kognitif, afektif, dan psikomotor anak menuju ke arah pembelajaran yang bermakna serta guru harus siap untuk berubah dari metode yang konvensional kepada metode pembelajaran yang terkini dengan mengikuti perubahan zaman dan globalisasi.

Perkembangan anak harus menjadi titik tolak seorang guru dalam 


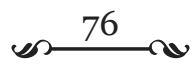

melaksanakan proses pembelajaran yang kreatif dan menyenangkan, dan segala sesuatu aktivitas yang dilakukan oleh guru harus mengacu kepada kompetensi, potensi, kemampuan, serta tingkat perkembangan anak sesuai dengan tingkatan usia dan kesanggupan dalam penerimaan materi pembelajaran.

Setidaknya ada tiga aspek yang harus ditempuh oleh seorang guru dalam meningkatkan profesionalisasi melalui sertifikasi dalam jabatan seperti aspek personality guru (kemampuan, potensi akademik), aspek perkembangan anak yang perlu diperhatikan oleh seorang guru dalam melakukan proses pembelajaran yang berfokus pada anak, dan aspek desain pembelajaran, serta pengakuan seorang guru dalam memenuhi segala kompetensi-kompetensi yang harus dilaksasanakan agar tercipta guruguru yang memenuhi persyaratan dalam menuju guru yang profesional. Langkah-langkah ini diharapkan akan meningkatkan profesionalisme dan peningkatan sertifikasi seorang guru, sehingga mutu dan kualitas pendidikan dapat terangkat pada masa yang akan datang. 


\section{。 \\ DAFTAR PUSTAKA}

Agung, Iskandar. 2010. Meningkatkan Kreativitas Pembelajaran Bagi Guru. Jakarta Timur: PT. Bestari Buana Murni.

Asmani, Jamal Ma'mur. 2011. 7 Tips Aplikasi PAKEM (Pembelajaran Aktif, Kreatif, Efektif, dan Menyenangkan). Jogjakarta: Diva Press.

Brocklehurst, B. 1971. Response to Music: Principles of Music Education. London: Alden \& Mowbray Ltd.

Djohan. 2005. Psikologi Musik. Yoyakarta: Buku Baik.

Jamalus. 1988. Pengajaran Musik melalui Pengalaman Musik. Jakarta: Depdikbud.

Kemdikbud. 2013. Implikasi Kurikulum 2013. Jakarta: Kementerian Pendidikan dan Kebudayaan.

Muhammad, As'adi. 2010. Deteksi Bakat dan Minat Anak Sejak Dini. Jogjakarta: Garailmu.

Mukminan, dkk. 1998. Belajar dan Pembelajaran. Yogyakarta: IKIP Yogyakarta.

Mulyasa, E. 2003. Kurikulum Berbasis Kompetensi: Konsep, Karakteristik, dan Implementasi. Bandung: Remaja Rosdakarya.

Mulyasa, E. 2007. Menjadi Guru Profesional; Menciptakan Pembelajaran Kreatif dan Menyenangkan. Bandung: Remaja Rosdakarya.

Munandar, U. 1999. Kreativitas dan Keberbakatan. Strategi Mewujudkan Potensi Kreatif dan Bakat. Jakarta: PT. Gramedia Pustaka Utama.

Pramono, Octavia. 2015. Temukan Sedini Mungkin Keajaiban Potensi Anak Anda. Yogyakarta: In Azna Books.

Prawiradilaga, Dewi Salma. 2008. Prinsip Desain Pembelajaran. Jakarta: Kencana.

Rusydie, Salman. 2011. Prinsip-Prinsip Manajemen Kelas; Tuntunan Kreatif dan Inovatif untuk keberhasilan Kegiatan Belajar-Mengajar. Jogjakarta: Diva Press.

Suprijono, Agus. 2009. Cooperative Learning; Teori dan Aplikasi PAIKEM. Yogyakarta: Pustaka Pelajar.

Sternberg, J. Robert. 1999. Handbook of Creativity. New York: Cambridge University Press.

Syah, Muhibin. 2004. Psikologi Pendidikan dengan Pendekatan Baru. Bandung: Remaja Rosdakarya. 